\title{
Role of fulvic acid on the reduction of cadmium toxicity on tilapia (Oreochromis niloticus)
}

\author{
A. E. Noor El Deen, M. S. Zaki \& H. A. Osman \\ Hydrobiology Department, Veterinary Division, \\ National Research Centre, Egypt
}

\begin{abstract}
The effect of fulvic acid on cadmium (Cd) toxicity, the impact on fish immunological, and haematological changes in Nile tilapia (Oreochromius niloticus) were studied. The fish $(100 \pm 10 \mathrm{~g})$ were exposed to $10 \mathrm{ppm} \mathrm{Cd}$ alone or with $0.1,0.2$ and $0.3 \mathrm{ppm}$ for 15 and 45 days. Cd exposure reduced significantly $(\mathrm{P}<0.04)$, for example the erythrocyte count $(\mathrm{RBCs})$, haemoglobin content $(\mathrm{Hb})$, haematocrit value $(\mathrm{Hct})$, mean cell haemoglobin $(\mathrm{MCH})$ and mean cell haemoglobin concentration. These parameters were improved when fulvic acid was applied with $\mathrm{Cd}$. The values of $\mathrm{RBCs}, \mathrm{Hb}, \mathrm{Hct}, \mathrm{MCH}$ and $\mathrm{MCHC}$ were increased significantly in the control fish group. The addition of fulvic acid to $\mathrm{Cd}$ contaminated medium considerably reduced metal absorption and accumulation in fish tissues, while metals in water and faeces increased. Fish exposed to $\mathrm{Cd}$ alone accumulated 2.15 and $5.970 \mathrm{mg} \mathrm{Cd} / \mathrm{g}$ dry weight in the liver tissue over 15 and 45 days, respectively. Cd reduced significantly to 1.292 and 4.16.; 0.92 and 3.791 ; and 0.41 and $2.43 \mathrm{mg} \mathrm{Cd} / \mathrm{g}$ dry weight tissue in fish exposed to $0.1,0.2$ and $0.3 \mathrm{~g}$ fulvic acid/L over 15 and 45 days, respectively. Similar trends were observed in gills and musculature.
\end{abstract}

Keywords: Nile tilapia, cadmium, immunological, fulvic acid, haematology, liver, gills, musculature.

\section{Introduction}

Nile tilapia are considered the most popular widely distributed, cheapest and intensively cultured fish in Egypt. The clinical picture in naturally infested and polluted Tilapia sp was revealed, some were aggregated on the water surface, and accumulated at the water inlet of the pond and air pump of aquaria. Almost all appeared dull with a loss of escape reflex (Eissa et al. [1] and Eaton and 
Stinson [2]). The present study reveals that the fish exposed to $\mathrm{Cd}$ alone showed significant reduction in RBCs, Hb and Hct, compared with those exposed to $\mathrm{Cd}$ with different levels of fulvic acid. The reduction of these parameters in Nile tilapia, O niloticus, at sublethal levels of cadmium might be due to the destruction of mature RBCs and the inhibition of erythrocyte production due to reduction of haemsynthesis, which is affected by pollutants (James and Sampath [3]). Also, the decrease in the RBC count may be attributed to haematopathology or acute haemolytic crisis that results in severe anaemia in most vertebrates, including fish species exposed to different environmental pollutants (Yamawaki et al. [4]) or it may be that the decrease in RBCs can attributed to the reduction of growth and other food utilization parameters, which results in sever anaemia (Wintrobe [5]). Moussa [6] found a significant decreased in total erythrocyte count, haemoglobin content, haematocrit value and mean corpuscular haemoglobin concentration in air breathing fish, Channa punctatus, after exposure to a sublethal dose of $\mathrm{Cd}(29 \mathrm{mg} \mathrm{Cd} / \mathrm{L})$. The addition of fulvic acid improves the haematological parameters (RBCs, Hb and Hct), which indicates the capability of fulvic acid to chelate Cd from the media. Subsequently, the Cd toxicity was reduced. These results are in agreement with those of Snedecor and Cochran [7], who observed that Oreochromis mossambicus exposed to copper along with fulvic acid showed a significant improvement in blood parameters over those of copper alone. The calculated blood indices $\mathrm{MCV}, \mathrm{MCH}$ and $\mathrm{MCHC}$ have a particular importance in anaemia diagnosis in most animals (Coles, 1986). The perturbations in these blood indices (increased MCV, decreased $\mathrm{MCH}$ and $\mathrm{MCHC}$ ) may be attributed to a defence against $\mathrm{Cd}$ toxicity through the stimulation of erythropiosis or may be related to the decrease in $\mathrm{RBCs}, \mathrm{Hb}$ and Hct due to the exaggerated disturbances that occurred in both metabolic and hemopoietic activities of fish exposed to sublethal concentration of pollutants (Huang et al. [8]). The present results indicate that fulvic acid is effective in removing $\mathrm{Cd}$ from water, and reducing $\mathrm{Cd}$ bioaccumulation in fish. Particulate organic matter can scavenge metal from water and help to reduce metal from fish. These results are in agreement with Shalaby [9], whose study shows that any agent that can remove $\mathrm{Cd}$ from water helps to reduce the bioaccumulation of this metal in fish. The present study showed that the addition of fulvic acid to the $\mathrm{Cd}$ media reduced significantly $(\mathrm{P}<0.05)$ the $\mathrm{Cd}$ level in water and metal uptake as compared to fish exposed to $\mathrm{Cd}$ alone. The $\mathrm{Cd}$ concentration in water was $9.31 \mathrm{mg} / \mathrm{L}$ and it decreased significantly $(\mathrm{P}<0.05)$. The $\mathrm{Cd}$ accumulation in the liver, gills and muscle of fish exposed to $\mathrm{Cd}$ alone was higher than that of fulvic acid. These results suggest that fulvic acid could chelate $\mathrm{Cd}$ ions producing a stable complex, thus reducing the chance for metal uptake by tissues. Besides, the fulvic acid eliminated a greater amount of $\mathrm{Cd}$ from the body through faeces. The formation of a $\mathrm{Cd}$-fulvic acid complex in water and the elimination of a greater amount of $\mathrm{Cd}$ in faeces evidently reduced the metal burden in tissues and thereby improved the haematological parameters of fish exposed to Cd. Planas-Bohne and Lehman [10] found a low level of cadmium in tissues due to increased excretion of metals through faeces and urine when rats were administered $\mathrm{Cd}$ intravenously along with fulvic acid (Table 1). 
Table 1: Changes in cadmium residue in water $(\mathrm{mg} \mathrm{Cd} / \mathrm{L})$, liver, gills, musculature and faeces (mg $\mathrm{Cd} / \mathrm{g}$ dry weigh) of Nile tilapia (O. niloticus) exposed to $\mathrm{Cd}$ with or without fulvic acid (FA).

\begin{tabular}{|c|c|c|c|c|c|c|c|c|c|}
\hline Items & \multirow[t]{2}{*}{ Water } & \multicolumn{2}{|c|}{ Liver } & \multicolumn{2}{|c|}{ Gills } & \multicolumn{2}{|c|}{ Musculureate } & \multicolumn{2}{|c|}{ Faeces } \\
\hline Period/days & & 15 & 45 & 15 & 45 & 15 & 45 & 15 & 45 \\
\hline Control & 0.041 & $0.048^{\mathrm{a}}$ & $0.055^{\mathrm{a}}$ & $0.038^{\mathrm{a}}$ & $0.039^{\mathrm{a}}$ & $0.023^{\mathrm{a}}$ & $0.076^{\mathrm{a}}$ & $0.003^{\mathrm{a}} \mathrm{b}$ & $0.005^{\mathrm{a}} \mathrm{b}$ \\
\hline $\mathrm{Cd}$ & $\begin{array}{c} \pm 0.02 \\
9.31\end{array}$ & $\begin{array}{l} \pm 0.02 \\
2.15^{\mathrm{b}}\end{array}$ & $\begin{array}{l} \pm 0.004 \\
5.971^{\mathrm{b}}\end{array}$ & $\begin{array}{l} \pm 0.02 \\
1.36^{\mathrm{b}}\end{array}$ & $\begin{array}{l} \pm 0.04 \\
2.56^{\mathrm{b}}\end{array}$ & $\begin{array}{l} \pm 0.002 \\
0.476^{\mathrm{b}}\end{array}$ & $\begin{array}{l} \pm 0.005 \\
1.077^{\mathrm{b}}\end{array}$ & $\begin{array}{l} \pm 0.018 \\
0.153^{\mathrm{b}}\end{array}$ & $\begin{array}{l} \pm 0.02 \\
0.189^{\mathrm{b}}\end{array}$ \\
\hline $\mathrm{Cd}+0.1 \mathrm{~g}$ & $\begin{array}{l} \pm 0832 \\
7.15\end{array}$ & $\begin{array}{r} \pm 0.253 \\
1.292^{c}\end{array}$ & $\begin{array}{l} \pm 0.85 \\
4.16^{\mathrm{b}}\end{array}$ & $\begin{array}{c} \pm 0.085 \\
0.65^{\mathrm{c}}\end{array}$ & $\begin{array}{c} \pm 0.276 \\
1.07^{\mathrm{c}}\end{array}$ & $\begin{array}{c} \pm 0.06 \\
0.343^{\mathrm{cb}}\end{array}$ & $\begin{array}{l} \pm 0.15 \\
0.665^{c}\end{array}$ & $\begin{array}{c} \pm 0.018 \\
0.940^{c}\end{array}$ & $\begin{array}{l} \pm 006 \\
2.067^{c}\end{array}$ \\
\hline $\begin{array}{c}\mathrm{FA} / 1 \\
\mathrm{Cd}+0.2 \mathrm{~g}\end{array}$ & $\begin{array}{c} \pm 0.34 \\
3.78\end{array}$ & $\begin{array}{c} \pm 0.056 \\
0.95^{\mathrm{d}}\end{array}$ & $\begin{array}{l} \pm 0.45 \\
3.791^{b}\end{array}$ & $\begin{array}{l} \pm 0.06 \\
0.394^{\mathrm{d}}\end{array}$ & $\begin{array}{l} \pm 0.11 \\
0.85^{\mathrm{c}}\end{array}$ & $\begin{array}{l} \pm 0.04 \\
0.33^{\mathrm{cb}}\end{array}$ & $\begin{array}{l} \pm 0.021 \\
0.383^{d}\end{array}$ & $\begin{array}{l} \pm 0.03 \\
2.34^{\mathrm{d}}\end{array}$ & $\begin{array}{l} \pm 0.143 \\
5.443^{\mathrm{d}}\end{array}$ \\
\hline $\begin{array}{c}\mathrm{FA} / 1 \\
\mathrm{Cd}+0.3 \mathrm{~g}\end{array}$ & $\begin{array}{c} \pm 0.01 \\
1.73\end{array}$ & $\begin{array}{c} \pm 0.054 \\
0.42^{\mathrm{e}}\end{array}$ & $\begin{array}{l} \pm 0.29 \\
2.45^{\mathrm{c}}\end{array}$ & $\begin{array}{l} \pm 0.052 \\
0.266^{\mathrm{d}}\end{array}$ & $\begin{array}{l} \pm 0.06 \\
0.71^{\mathrm{c}}\end{array}$ & $\begin{array}{l} \pm 0.08 \\
0.216^{c}\end{array}$ & $\begin{array}{r} \pm 0.034 \\
0.217^{\mathrm{d}}\end{array}$ & $\begin{array}{c} \pm 0.069 \\
5.282^{\mathrm{e}}\end{array}$ & $\begin{array}{l} \pm 0.345 \\
7.456^{\mathrm{e}}\end{array}$ \\
\hline $\mathrm{FA} / 1$ & \pm 0.02 & \pm 0.034 & \pm 0.23 & \pm 0.073 & \pm 0.42 & \pm 0.03 & \pm 0.025 & \pm 0.32 & \pm 0.528 \\
\hline
\end{tabular}

\section{Polluted tilapia.....why?}

Cadmium is one of the most toxic heavy metals that enters the environment from natural sources and as a result of man's activity, such as recycling of scrap metal, electroplating, industry manufacturing vinyl plastics, electrical contacts, metallic and plastic pipes. Tilapia have the capability of concentrating metals by feeding and metabolic processes, which can lead to the accumulation of high concentrations of metals in their tissues. The reduction of toxic elements, such as cadmium, in aquatic environments is needed by any acceptable method.

\subsection{Are there solutions?}

The most widely used technique for the removal of toxic elements involves the process of neutralization and metal hydroxide precipitation (Hiemesh and Mahadevaswamy [11]). Chemicals can effectively remove certain toxic elements from industrial wastes or polluted media, but it is usually costly. However, there are some cheap natural products that are also free from undesirable side effects. In recent years, the remobilization of metals by synthetic anthropogenic chelating agents has received much attention. The literature reported a number of chelators that have been used for chelate-induced hyper accumulation (Khangarot and Tripathi [12]). Natural compounds, such as fulvic acid, are known to be effective chelating agents of heavy metals (Karuppasamy [13]).

\subsection{Why fulvic acid?}

Fulvic acid is the most commonly used chelator because of its small molecular weight and strong chelating ability for different heavy metals (Litchfield and 
Wileoxon [14] and Donor and William [15]). Metal bioaccumulation can occur via complication, coordination, chelation, ion exchange and other processes of greater or lesser specificity. Bioaccumulation processes are sometimes due to active (metabolism dependent) metal accumulation by living cells. In spite of the amount of data published on the effect of water borne exposure of cadmium and fulvic acid singly, information on the effects of a $\mathrm{Cd} /$ fulvic acid mixture on aquatic organisms are limited and not uniform. Therefore, fulvic acid appears to be a promising tool to control cadmium pollution in aquaculture. The present study, short- and long-term bioassays were designed to evaluate the influence of fulvic acid on the retention of cadmium in water. It was carried out to investigate the effect of fulvic acid on the reduction of the toxicity of cadmium, to enhance the change of blood parameters and enzymes and to assess its impact on some physiological parameters of Nile tilapia (Oreochromis niloticus).

\section{Practical procedures}

The present study showed that the addition of fulvic acid to $\mathrm{Cd}$ contaminated media reduced significantly the $\mathrm{Cd}$ level in water and helped to eliminate $\mathrm{Cd}$ from the fish body, which in turn improved the clinical signs and the haematological parameters as compared to fish exposed to cadmium alone.

\subsection{Collecting sample tilapia}

A healthy 75 fish of Nile tilapia Oreochromis niloticus weighing $(100 \pm 10 \mathrm{~g}) /$ fish were collected from the ponds of Kafr Eel Sheikh governorate fish farms, Egypt. Fish were acclimated in cement fish ponds for two weeks. Acclimated fish were exposed to different concentrations of cadmium and mortality was observed for 96-h. A static renewable bioassay method (Duncan [16]) was adopted for the determination of 96-h median lethal probity analysis; Santschi [17] was followed for the calculation of $96 \mathrm{hr} \mathrm{LC}_{50}$. A control group was maintained in metal-free tap water. The $96 \mathrm{hr} \mathrm{LC} 50$ of cadmium for Oreochromis niloticus was $40 \mathrm{ppm}$. A stock solution of cadmium was prepared by dissolving $10.686 \mathrm{~g}$ of annular grad cadmium sulphate $\left(\mathrm{CdSO}_{4}-8 / 3 \mathrm{H}_{2} \mathrm{O}\right)$ in $1 / \mathrm{L}$ of distilled water and diluted with water to obtain the desired concentration $(10 \mathrm{ppm})$ for this experiment. The fish were distributed randomly in five cement ponds at a rate of 15 fish/aquarium, which containing aerated tap water. These aquaria were divided into five groups with three replicates each per group. Fish were fed frequently on a diet containing $25 \%$ crude protein $(\mathrm{CP})$ at a rate of $3 \%$ of live body weight twice daily for 15 and 45 days. Siphoning of three quarters of the aquariums was done every day for waste removal and it was replaced by an equal volume of water containing the same concentration of $\mathrm{Cd}$ and fulvic acid. Dead fish were removed and recorded daily.

\subsection{Sample classification}

The first group was free of $\mathrm{Cd}$ and fulvic acid and maintained as a control. The second group was exposed to $10 \mathrm{ppm}$ of $\mathrm{Cd} \mathrm{SO}_{4}$ only. The third, fourth and fifth 
groups were exposed to $10 \mathrm{mg} \mathrm{Cd} / \mathrm{L}$ and $0.1,0.2$ and $0.3 \mathrm{~g}$ fulvic acid/L, respectively. Each aquarium was supplied with compressed air via air-stones from air pumps. A well-aerated water supply was provided from a storage fibreglass tank. The temperature was adjusted at $27 \pm 1^{\circ} \mathrm{C}$ by means of thermostats (Table 2).

Table 2: $\quad$ Field experimental groups and their notation.

\begin{tabular}{|c|c|c|}
\hline S. No. & Groups in field ponds & Nation \\
\hline 1 & Control $($ metal free water $)$ & $\mathrm{C}$ \\
\hline 2 & Cadmium $(10 \mathrm{ppm})$ alone & $\mathrm{Cd}$ \\
\hline 3 & Cadmium $(10 \mathrm{ppm})+0.1 \mathrm{~g}$ fulvic acid $/ 1$ & Cd fulvic acid 1 \\
\hline 4 & Cadmium $(10 \mathrm{ppm})+0.2$ fulvic acid $/ 1$ & Cd fulvic acid 2 \\
\hline 5 & Cadmium $(10 \mathrm{ppm})+0.3 \mathrm{~g}$ fulvic acid $/ 1$ & Cd fulvic acid 3 \\
\hline
\end{tabular}

\section{3 $\mathrm{Cd}$ residue}

Cadmium sulphate and fulvic acid was obtained from the El-Nasr chemical and Grotech companies (Egypt), respectively, and prepared in aquatic solution to provide the required concentrations of cadmium and fulvic acid. Cadmium was measured in the water, liver, gills, musculature and faeces according to method of Norvell [18].

\subsection{Statistical analysis}

The obtained data were subjected to analysis of variance between means and were done at the 5\% probability level, using Duncan's new multiple range test by Spraggue [19].

\section{Results}

The present study showed that addition of fulvic acid to Cd contaminated media reduced significantly the $\mathrm{Cd}$ level in the water and helped to eliminate metal from the fish body (liver, gills, musculature and faeces ) and in turn improved the biochemical parameters as compared to fish exposed to $\mathrm{Cd}$ alone (see Table 2).

\subsection{Clinical examination}

The clinical examination of most examined fish showed asphyxia, some aggregated on the surface, accumulated at the water inlet of the pond and the air pump of aquaria. Others appeared dull with loss of escape reflex.

\subsubsection{Haematological parameters}

The results of erythrocyte count (RBCs), haemoglobin content $(\mathrm{Hb})$ and haematocrit value (Hct) obtained from the fish exposed to a sublethal dose of $\mathrm{Cd}$ 
Table 3: Changes in mean cell volume (MCV), mean cell haemoglobin $(\mathrm{MCH})$ and mean cell haemoglobin concentration $(\mathrm{MCHC})$ in the blood of Nile tilapia (O. niloticus) exposed to $\mathrm{Cd}$ with or without fulvic acid (FA).

\begin{tabular}{|lllllll||}
\hline Items & MCV & & MCH & & MCHC \\
Period & 15 days & 45 days & 15 days & 45 days & 15 days & 45 days \\
Control & $95.32^{\text {ad }}$ & $100.02^{\mathrm{a}}$ & $34.35^{\mathrm{a}}$ & $43.21^{\mathrm{a}}$ & $34.77^{\mathrm{a}}$ & $43.32^{\mathrm{a}}$ \\
& \pm 1.86 & \pm 2.243 & \pm 0.342 & \pm 1.432 & \pm 1.121 & \pm 0.928 \\
$\mathrm{Cd}$ & $106.93^{\mathrm{b}}$ & $106.75^{\mathrm{b}}$ & $33.02^{\mathrm{b}}$ & $36.56^{\mathrm{b}}$ & $31.15^{\mathrm{b}}$ & $37.27^{\mathrm{b}}$ \\
& & & & & & \\
& \pm 2.23 & \pm 0.874 & \pm 0.177 & \pm 0.846 & \pm 0.909 & \pm 1.85 \\
$\mathrm{Cd}+0.1 \mathrm{~g}$ & $93.45^{\mathrm{a}}$ & $95.71^{\mathrm{a}}$ & $34.52^{\mathrm{a}}$ & $32.45^{\mathrm{b}}$ & $37.21^{\mathrm{a}}$ & $33 . .77^{\mathrm{b}}$ \\
& & & & & & \\
$\mathrm{FA} / 1$ & \pm 2.05 & \pm 4.26 & \pm 1.23 & \pm 1.17 & \pm 1.26 & \pm 1.49 \\
$\mathrm{Cd}+0.2 \mathrm{~g}$ & $96.24^{\mathrm{a}}$ & $98.77^{\mathrm{a}}$ & $33.23^{\mathrm{a}}$ & $36.76^{\mathrm{bc}}$ & $34.06^{\mathrm{ac}}$ & $37.40^{\mathrm{b}}$ \\
& & & & & & \\
$\mathrm{FA} / 1$ & \pm 2.64 & \pm 0.909 & \pm 1.72 & \pm 1.49 & \pm 1.76 & \pm 1.20 \\
$\mathrm{Cd}+0.3 \mathrm{~g}$ & $101.1^{\mathrm{db}}$ & $107.95^{\mathrm{b}}$ & $32.85^{\mathrm{a}}$ & $37.02^{\mathrm{ac}}$ & $33.34^{\mathrm{cb}}$ & $34.87^{\mathrm{b}}$ \\
& & & & & \\
$\mathrm{FA}$ & \pm 2.512 & \pm 2.241 & \pm 1.702 & \pm 1.576 & \pm 0.941 & \pm 1.68 \\
\hline
\end{tabular}

Table 4: Changes in erythrocyte (count $x$ 106/mm3), haemoglobin content $(\mathrm{g} / 100 \mathrm{ml})$ and haematocrit value $(\%)$ in the blood of Nile tilapia (O. niloticus) exposed to $\mathrm{Cd}$ with and without fulvic acid (FA).

\begin{tabular}{|lllllll|}
\hline Items & \multicolumn{2}{l}{ Erythrocyte count (RBCs) } & \multicolumn{2}{l}{ Haemoglobin (HB) } & \multicolumn{2}{l}{ Haematocrit value (Hct) } \\
Period & 15 days & 45 days & 15 days & 45 days & 15 days & 45 days \\
Control & $1.58^{\mathrm{a}}$ & $1.714^{\mathrm{a}}$ & $5.48^{\mathrm{a}}$ & $7.315^{\mathrm{a}}$ & $15 . .31^{\mathrm{a}}$ & $17 . .32^{\mathrm{a}}$ \\
& & & & & & \\
& \pm 0.073 & \pm 0.051 & \pm 0.353 & \pm 0.133 & \pm 0.308 & \pm 1.665 \\
Cd & $1.268^{\mathrm{b}}$ & $1.06^{\mathrm{b}}$ & $4.21^{\mathrm{b}}$ & $4.12^{\mathrm{c}}$ & $13 . .5^{\mathrm{b}}$ & $12.01^{\mathrm{b}}$ \\
& & & & & & \\
& \pm 0.064 & \pm 0.073 & \pm 0.235 & \pm 0.354 & \pm 0.47 & \pm 0.576 \\
Cd+0.1g & $1.572^{\mathrm{a}}$ & $1.57^{\mathrm{d}}$ & $4.54^{\mathrm{ab}}$ & $5.12^{\mathrm{b}}$ & $14.66^{\mathrm{a}}$ & $15.05^{\mathrm{a}}$ \\
& & & & & & \\
FA/1 & \pm 0.064 & \pm 0.023 & \pm 0.395 & \pm 0.136 & \pm 1.454 & \pm 0.76 \\
Cd+0.2g & $1.56^{\mathrm{a}}$ & $1.786^{\mathrm{ac}}$ & $5.17^{\mathrm{ab}}$ & $6.605^{\mathrm{b}}$ & $15.02^{\mathrm{a}}$ & $17.65^{\mathrm{a}}$ \\
& & & & & & \\
EDTA/1 & \pm 0.086 & \pm 0.032 & \pm 0.458 & \pm 0.305 & \pm 1.72 & \pm 0.916 \\
Cd+0.3g & $1.956^{\mathrm{c}}$ & $2.01^{\mathrm{c}}$ & $6.464^{\mathrm{c}}$ & $7.68^{\mathrm{a}}$ & $20.0^{\mathrm{c}}$ & $22.02^{\mathrm{c}}$ \\
& & & & & & \\
FA/1 & \pm 0.086 & \pm 0.063 & \pm 0.277 & \pm 0.133 & \pm 0.365 & \pm 1.471 \\
\hline
\end{tabular}


(10 mg/l) alone or with different doses of fulvic acid are given in Table 4. Table 3 shows that the RBCs, HB and HCt were reduced in fish exposed to Cd over both periods and they were less than that of the control $(\mathrm{P}<0.05)$ The RBCs count decreased significantly in fish exposed to $\mathrm{Cd}$ at 15 and 45 days. On the other hand, these parameters returned to the normal values and increased significantly in fish exposed to $\mathrm{Cd}$ with 0.2 and $0.3 \mathrm{~g}$ of fulvic acid/L for 15 and 45 days. These values increased significantly in fish exposed to $\mathrm{Cd}$ with $0.3 \mathrm{~g}$ fulvic acid/L. Blood parameter were improved in fish exposed to $\mathrm{Cd}$ with different levels of fulvic acid. The blood indices calculated from the mean values of blood parameters for the aforementioned treatments are given in Table 3.

Data shows that the $\mathrm{MCV}$ increased significantly in fish exposed to $\mathrm{Cd}$ alone, while the $\mathrm{MCH}$ and $\mathrm{MCHC}$ decreased significantly in fish exposed to $\mathrm{Cd}$ only when compared with the control. These parameters increased with increasing of exposure time of fish to $\mathrm{Cd}$. The addition of fulvic acid to $\mathrm{Cd}$-polluted media maintained the $\mathrm{MCV}, \mathrm{MCH}$ and $\mathrm{MCHC}$ at levels close to those of the control.

\section{Recommendation}

From the present study, it is recommended that an optimum dosage of $0.3 \mathrm{~g}$ fulvic acid/L can effectively chelate $\mathrm{Cd}$ from contaminated water. Hence, a scientific method of detoxification is essential to improve the health of fish in any stressed environmental conditions.

\section{References}

[1] Eissa, I.A.M and Fatma. M. Fakhry (1994): Clinical picture and residue levels of locally used pesticides (field dose) in some freshwater and marine fishes. J. Egypt Vet. Med. Res., 3, 1, 96-107.

[2] Eaton, D. L and Stinson, M. D. (1983): Concentration of lead, cadmium, mercury and copper in the cray fish (Pacifasticus leniusculus) obtained from a lake receiving urban runoff. Arch. Environ. Contam. Toxicol., 12: 693- 700 .

[3] James, R. and Sampath, K (1999): Effect of the ion- exchanging agent, Zeolite, on reduction of cadmium toxicity: an experimental study on growth and elemental uptake in Heteropneustes fossilis (Bloch). J. Aqua. Trop., 14 (1) $65-74$.

[4] Yamawaki, K.; Hashimoto, W.; Fujii, K.; Koyama, J.; Ikeda, Y. and Ozaki, H. (1986): Hematological changes in carp exposed to low cadmium concentration. Bull of the Japanese. Soc. Sci. Fish., 59 (3):459- 466.

[5] Wintrobe, M. M (1978): Clinical hematology. Henry Kimpton, London, pp: 448.

[6] Moussa, M. A. (1999): Biological and physiological studies on the effect of the gramoxon and stomp herbicides on Nile tilapia (Oreochromis niloticus). Fact. Sci. Zool. Dep. Cairo. Univ.,200p (Ph.D. Thesis)

[7] Snedecor, G. W. and Cochran, W. G. (1982): Statistical Methods. 6th edition. Iowa State Univ. Press., Amer., IA, USA, pp 593. 
[8] Huang, J. W.; Chen, J.; Berti, W. R. and Cunningham S. D (1997): Phytoremediation of Pb-contaminated soils: Role of synthetic chelates in lead phytoextraction. Environ. Sci. Technol., 31: 800- 805.

[9] Shalaby, A. M. (2001): Protective effect of ascorbic acid against mercury intoxication in Nile tilapia (Oreochromius niloticus). J. Egypt. Acad. Soc. Environ. Develop., (D- Environmental studies), 2 (3):79-97.

[10] Planas-Bohne, F and Lehman, M (1983): Influence of chelating agent on the distribution and excretion of cadmium in rats. Toxicol. Appl. Pharmacol., 67: 408- 416.

[11] Hiemesh, S. and Mahadevaswamy, M. (1994): Sorption potential of biosorban: for the removal of copper. Indian. J. Environ. Hlth., 36: 165169.

[12] Khangarot, B. S and Tripathi, D. M (1991): Changes in humoral and cellmediated immune responses and in skin and respiratory surfaces of cat fish Saccobranchus fossillis, following copper exposure. Ecot. Envir. Safety, 22 (3): 291- 308.

[13] Karuppasamy, R.; Subathra, S and Puvaneswari, S. (2005): Haematological responses to exposure to sublethal concentration of cadmium in air breathing fish, Channa punctatus (Bloch). J. Environ Biol., 26(1):123-8.

[14] Litchfield, J. T and Wileoxon, F. (1949): A simplified method for evaluating dose- effect experiments. J. Pharmacol. . Exp. Ther., 96:59-113.

[15] Donor and William R. (1993). Humic, Fulvic and Microbial Balance: Organic Soil Conditioning. Evergreen Colorado: Jackson Research Center.

[16] Duncan, D.B. (1955): Multiple range and multiple (F) test. Biometrics, 11: 1- 42.

[17] Santschi, P. H (1988): Factors controlling the biogeochemical cycle of trace elements in fresh and coastal waters as revealed by artificial radioisotopes. Limnology and oceanography, 33:848- 886.

[18] Norvell, W.A (1991): Reactions of metal chelates in soil and nutrient solutions In: Mortvedt, J.J., Cox, F.R., Shuman, L. M and Welch, R. M., Editors, 1991. Micronutrients in Agriculture, $2^{\text {nd }}$ Edition, Soil. Science of America, Madison, Wisconnsin, pp. 187- 227.

[19] Spraggue, J.B (1973): The ABCs of pollutant bioassay using fish In Biological methods for Assessment of water quality. ASTM 528. Amer.testing. Material, pp.6-30. 